\title{
Monod Kinetics and Modelling Equations of Quercetin Extraction from Leaves of Indian Gooseberry
}

\author{
D.V Surya Prakash, Anand Kumar Nelapati, T. Mohammad Munawar
}

\begin{abstract}
Quercetin flavonoid are family of herbal plant compounds shows various pharmacological activities. In the present study, quercetin extraction show best results in the fermentation process than compare to extraction process due to biotransformation process. The highest concentration of quercetin was found to be $8.8 \mu \mathrm{g} / \mathrm{ml}$ from the extraction process, and the concentration was found to be $9.6 \mu \mathrm{g} / \mathrm{ml}$ from the fermentation process. The Extracts of the fermented process are shown with the maximum specific growth rate and the maximum yield factor $(\mathrm{Yx} / \mathrm{s})$ of Bacillus cereus are $0.3541 \mathrm{hr}-1$ and $0.234 \mu \mathrm{g} / \mathrm{ml}$. The extracts of non fermentation process (extraction) are shown the modelling equation for the quercetin yield extract was $E s=0.0733(1-e-0.2767 t)$. The model allowed fit accordance with the experimental data by producing average absolute relative deviation about $9.53 \%$.
\end{abstract}

Keywords: Quercetin, Fermentation, Extraction, Indian Gooseberry, Bacillus cereus.

\section{INTRODUCTION}

Indian Gooseberry is one of the most important medicinal herbal plants. It scientific name was Phyllanthus emblica and commonly known as amla in India. It belongs to Phyllanthaceae family [1]. All parts of the plant are used in various Ayurvedic drug preparations, including the flower, leaves, seeds, root, stem and fruit. According to Ayurveda, Indian Gooseberry is tikta (bitter) and rasa (taste). It contains high amount of vitamin C, poly phenols, bio- flavonoids (quercetin, kaempferol and rutin), and emblicanin. Indian Gooseberry is one of the best herbs for anti-oxidant, anti-arthritic, anti-inflammatory, anti-cancer and wound healing activities [2]. Bio flavonoids are known to play a vital role as antioxidant and high amount of flavonoids contains in the leaves of Indian Gooseberry [3]. These flavonoids are family of herbal plant compounds. Mainly quercetin

\section{Revised Manuscript Received on December 30, 2019.}

* Correspondence Author

Surya Prakash DV, Department of Biotechnology, Meerut Institute of Engineering and Technology,Meerut -250005 Uttar Pradesh, prakashsurya55@gmail.com..

Anand Kumar Nelapati, Department of Chemical Engineering, NITK, Surathkal, Mangalore -575025, India. Email: nelapatianandkumar@gmail.com

T. Mohammad Munawar*, Department of Biological and Chemical Engineering, Mekelle Institute of Technology (MIT), Mekelle University, Mekelle-1632, Ethiopia,munna686@gmail.com.

(C) The Authors. Published by Blue Eyes Intelligence Engineering and Sciences Publication (BEIESP). This is an open access article under the CC BY-NC-ND license (http://creativecommons.org/licenses/by-nc-nd/4.0/) flavonoid has shows various pharmacological activities [4]. It was extracted by various extraction methods such as soxhlet, supercritical fluid extraction and determination methods are thin-layer chromatography, high pressure liquid chromatography, electrochemical, spectrophotometry and capillary electrophoresis methods. Especially estimation of quercetin was carried out by using aluminum chloride method [5]. In the biological field, quercetin is obtained from the fermentation process by using Bacillus cereus. In this research work, the effect of quercetin production was investigated by studying the growth kinetic parameters through Monod kinetics such as specific growth rate $(\mu)$, maximum specific growth rate ( $\mu$ max) and yield factors of substrate (YX/S) and product (quercetin) (YP/X) by using the Bacillus cereus [6]. Similarly, the experimental modeling equation and average absolute relative deviation of quercetin was also investigated from the soxhlet extraction process. .

\section{MATERIAL AND METHODS}

\section{A. Plant material}

Leaves of Indian Gooseberry were collected, cleaned dried and powered. The powered leaf material was sieved by using 125 microns and stored in the air tight container.

\section{B. Chemicals}

Nutrient broth medium, aluminum chloride, potassium acetate, methanol, distilled water procured from S.R scientifics, TIrupathi, India.

\section{Microorganism}

Bacillus cereus was procured from the MTCC Chandigarh, India and stored at $4^{\circ} \mathrm{C}$ in refrigerator.

\section{Preparation of Extracts}

\section{i. Non Fermented extract}

24 grams of leaf powder were placed with care in the thimble and fixed firmly to the condenser. About $200 \mathrm{ml}$ of distilled water was used as a solvent, taken in the round bottom flask $[7,8]$. The total apparatus were positioned in the heater and a temperature not more than the boiling point of the solvent was maintained. Using the soxhlet apparatus $[9,10]$ facilitated the process of continuous extraction was for a period of 8hr which ultimately resulted in the collection of $1.0 \mathrm{ml}$ of crude extract from every $1 \mathrm{hr}$ used for quercetin estimation.

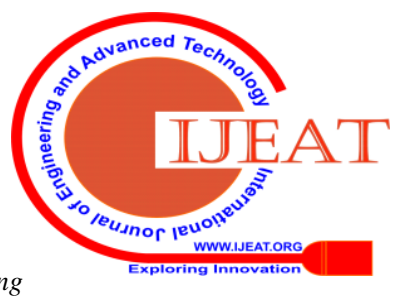




\section{ii. Fermented extract}

$100 \mathrm{ml}$ of Nutrient broth medium is autoclaved at $121^{\circ} \mathrm{C}$ for $15 \mathrm{~min}$ and distributed the nutrient broth into $250 \mathrm{ml}$ conical flasks. Bacillus cereus (1ml) was taken from culture medium and inoculated into above conical flasks in the vicinity of laminar air flow. Incubate the cultures in the orbital shaker incubator at $30^{\circ} \mathrm{C}$ temperature at $120 \mathrm{rpm}$ for $24 \mathrm{hr}$ [11].

When the microbial growth was observed, transfer to $40 \mathrm{ml}$ of water extract from leaves of Indian Gooseberry, which is produced by soxlet extraction process, into the various conical flasks individually. Before addition of Bacillus cereus, $10 \mathrm{ml}$ of $20 \%$ of glucose solution (carbon source) was added to water extract from leaves of Indian Gooseberry. Then flasks were incubated at $30^{\circ} \mathrm{C}$ for 4 to 5 days. After the specified incubation period, the fermented samples were filtered through whatmann filter paper and filtrate was centrifuged at $10,000 \mathrm{rpm}$ for $10 \mathrm{~min}$ at $4^{\circ} \mathrm{C}[12,6]$. After centrifugation, collect the supernatant as fermented sample and pellet as biomass (X). In the fermented sample, quercetin (P), rutin, and substrate (carbon source - glucose) concentration (S) were determined by using aluminum chloride spectrophotometer and DNS method.

\section{E. Estimation of Quercetin, Rutin, Glucose and $\beta$-Glucosidase enzyme}

\section{i. Quercetin}

Each $0.5 \mathrm{ml}$ of water extracts and fermented sample taken in each test tube and $1.5 \mathrm{ml}$ of methanol, $0.1 \mathrm{ml}$ of $10 \%$ aluminium chloride (AlCl3), $0.1 \mathrm{ml}$ of $1 \mathrm{M}$ potassium acetate and $2.8 \mathrm{ml}$ of distilled water were added. The mixture was allowed to stand for $30 \mathrm{~min}$ at room temperature. The absorbance of the reaction mixture was measured at $415 \mathrm{~nm}$ using spectrophotometer [13]. The quercetin was estimated with the help of calibration curve.

\section{ii. Rutin}

Each $0.5 \mathrm{ml}$ of water extracts and fermented sample taken in each test tube and add $0.5 \mathrm{ml}$ of $2 \%$ aluminium chloride $(\mathrm{AlCl} 3)$ solution dissolved in ethanol. The mixture was allowed to stand for $30 \mathrm{~min}$ at room temperature. The absorbance of the reaction mixture was measured at $420 \mathrm{~nm}$ using spectrophotometer [14]. The rutin was estimated with the help of calibration curve.

\section{iii. Glucose}

DNS method is used for estimation of carbon source glucose in the fermented sample. $1 \mathrm{ml}$ fermented sample taken in a test tube and make the volume to $1 \mathrm{ml}$ with distilled water. Add $1 \mathrm{ml}$ DNS reagent and boiled the test tube by using water bath at $5 \mathrm{~min}$. After the boiling process, that sample is dilute with and makeup to $10 \mathrm{ml}$ with distilled water. The absorbance of the reaction mixture was measured at $540 \mathrm{~nm}$ with the help of spectrophotometer [15].

\section{iv. $\beta$-Glucosidase}

$0.5 \mathrm{ml}$ of fermented sample taken in test tube. $1 \mathrm{ml}$ of $0.1 \mathrm{M}$ acetate buffer ( $\mathrm{pH} 5.0$ ) and $0.5 \mathrm{ml}$ of $10 \mathrm{mM}$ phosphate buffer, $\mathrm{pH} 7.0$ containing $0.2 \%$ of BSA solutions are added. After $15 \mathrm{~min}$ at $37^{\circ} \mathrm{C}$, add $2.0 \mathrm{ml}$ of sodium carbonate solution. The absorbance of the reaction mixture was measured at $400 \mathrm{~nm}$ with the help of spectrophotometer [16].

\section{F. Modelling development of quercetin}

The following hypothesis was employed in order to explain quercetin transport from the leaves of Indian Gooseberry to the bulk of the solvent. According to [14], the mass transfer coefficient is taken as a constant. The solvent in the extractor is completely mixed with extract and transfer resistance of the liquid phase is negligible and so, the quercetin concentration present in the solvent depends only on time. However, the transfer of the quercetin was a diffusion occurrence and was not depend on time. Therefore, the final form of the modelling equation [17] obtained from the extraction of quercetin by using soxhlet extractor can be expressed as $\mathrm{Eq}(1)$ :

$$
\mathrm{Es}=\mathrm{B}\left(1-e^{-\mathrm{Dt}}\right)
$$

Where, Es= grams of quercetin per gram of dried sample (mg/gm),

$$
\mathrm{t}=\text { extraction time }(\mathrm{hr}) \text { and } \mathrm{B} \& \mathrm{D}=\text { equation }
$$
constants.

\section{Average Absolute Relative Deviation (AARD):}

According to [14], AARD (Average Absolute Relative Deviation) can be calculated by

$$
A A R D=\frac{100}{N} \frac{\sum\left|\mathbf{E s}^{\mathrm{Exp}}-\mathbf{E s}^{\mathrm{Th}}\right|}{\mathbf{E s}^{\mathrm{Th}}}
$$

Where $\mathrm{N}=$ Number of experiments, $\mathbf{E s}^{\text {Exp }}=$ Experimental values of yield extract, $\mathbf{E} \mathbf{s}^{\text {Th }}=$ Theoretical values of yield extract.

\section{RESULTS}

\section{A. Non Fermented extract}

The maximum quercetin concentration was found to be $8.8 \mu \mathrm{g} / \mathrm{ml}$ from the water extract from leaves of Indian Gooseberry by soxhlet extractor at $9 \mathrm{hr}$. The modeling and theortical values of quercitin concentration with the time are shown in Table 1. In the comparison between polar solvents, non - polar solvents could extract quercetin at maximum yield except water, due to the hydrolysis and thermal degradation. It was observed that non - polar solvents were almost unable to extract the quercetin component. The final form of the suggested model equation [18] for the quercetin yield extract were $\mathrm{Es}=0.0733\left(1-e^{-0.2767 t}\right)$ where as Es are a yield extract from gram of chebulinic acid per gram of dried sample and $\mathrm{t}$ is a extraction time in hrs. The modeling and theortical values of Average absolute relative deviation values with the time are shown in Table 2. The model allowed good accordance with the experimental data by producing average absolute relative deviation from about 9.53\%.

\section{Modelling/theoritical equations:}

$$
\begin{aligned}
& \text { According to [18], Es = B }\left(1-\mathrm{e}^{-\mathrm{Dt}}\right) \\
& \mathrm{B}, \mathrm{D}=\text { constants } \& \text { at time }(\mathrm{t})=\text { infinity } \\
& \mathrm{Es} / \mathrm{B}=1-\mathrm{e}^{-\mathrm{Dt}} \\
& \mathrm{e}^{-\mathrm{Dt}}=1-\mathrm{Es} / \mathrm{B} \\
& \log _{e} \mathrm{e}^{-D t}=\log _{e}(1-E s / B) \\
& -D t \log _{e} \mathrm{e}=\log _{\mathrm{e}}(1-\mathrm{Es} / \mathrm{B}) \\
& -\mathrm{Dt}=\log _{\mathrm{e}}(1-\mathrm{Es} / \mathrm{B}) \\
& \mathrm{t}=-1 / \mathrm{D} \log _{\mathrm{e}}(1-\mathrm{Es} / \mathrm{B})
\end{aligned}
$$


SLOPE:

$(\mathrm{t})$



$\log _{9}(1-E s / B)$

Table 1: Modelling and Theoritical values

\begin{tabular}{|c|c|c|c|}
\hline Time (hr) & $\begin{array}{c}\text { Quercetin } \\
(\mu \mathrm{g} / \mathrm{ml})\end{array}$ & $\begin{array}{c}\text { Es }(\mathrm{mg} / \mathrm{g}) \text { of } \\
\text { dried sample }\end{array}$ & $\begin{array}{l}- \text { loge }(1- \\
\text { Es/B) }\end{array}$ \\
\hline 1 & 3.6 & 0.0299 & 0.5241 \\
\hline 2 & 4.3 & 0.0358 & 0.6706 \\
\hline 3 & 5.0 & 0.0416 & 0.8382 \\
\hline 4 & 5.6 & 0.0466 & 1.0098 \\
\hline 5 & 6.3 & 0.0524 & 1.2548 \\
\hline 6 & 7.1 & 0.0591 & 1.6438 \\
\hline 7 & 7.8 & 0.0649 & 2.1663 \\
\hline 8 & 8.5 & 0.0708 & 3.3782 \\
\hline 9 & 8.8 & $0.0733(\mathrm{~B})$ & $\alpha$ \\
\hline 10 & 8.2 & 0.0683 & 2.6851 \\
\hline 11 & 7.5 & 0.0624 & 1.9057 \\
\hline
\end{tabular}

Average absolute relative deviation:

AAD (Average Absolute Deviation) can be calculated by

AAD (Average Absolute Deviation) can be calculated by $A A D=\frac{1}{N} \sum\left|\mathbf{E s}^{\text {Exp }}-\mathbf{E s}^{\text {Th }}\right|_{=0.0301 / 8}$

$=0.003763(\mathrm{mg}$ of chebulinic acid per gm of dried sample)

AARD (Average Absolute Relative Deviation) can be calculated by



$$
\begin{aligned}
& =9.53 \%
\end{aligned}
$$

\section{B. Fermented extract}

The rate of product formation was estimated (Quercetin-P) based on the rate of substrate consumption (Glucose-S) and biomass (Pellate-X) production was studied for the selected Bacillus cereius was shown in Fig 1 and Table 3.

\section{i. Effect of maximum specific growth rate ( $\mu$ max)}

It was noticed that with increase in various time periods of product concentration (quercetin), biomass concentration (pellet) and there is a decrease in substrate concentration (glucose) through fermentation process by using Bacillus cereus. It was determined from the plot of $\mathrm{rs} / \mathrm{x}$ and $\mathrm{rx} / \mathrm{x}$ where rs is a rate of consumption of the substrate and rx is a rate of the cell growth $[19,20]$. So, the data points relating to reciprocal of biomass and substrate concentrations are required. This slope of the graph gives maximum specific growth rate ( $\mu$ max). The maximum specific growth rate for Bacillus cereus is $0.3541 \mathrm{hr}-1$. The results are shown in Table 4 and Fig .2.

\section{ii. Effect of Yield factor $(\mathrm{Yx} / \mathrm{s})$}

The amount of biomass formed per substrate consumed is known as Yield factor and it is determined from the plot of $\mathrm{rs} / \mathrm{x}$ and $\mathrm{rx} / \mathrm{x}[21,22]$. The maximum yield factor (Yx/s) of Bacillus cereus is $0.234 \mu \mathrm{g} / \mathrm{ml}$. The results were shown in Table 5 and Fig .3.

\section{DISCUSSION}

In the present work, the leaves of Indian Gooseberry were used to enhance the quercetin concentration by using soxhlet extraction process and its concentration was found to be 8.8 $\mu \mathrm{g} / \mathrm{ml}$. In the soxhlet extraction process, $24 \mathrm{~g}$ of powder is placed in a thimble and $200 \mathrm{ml}$ of water solvent is placed in the conical flask. The water droplets are coming out from the condenser and fall on the powder. In every cycle, only flavor color is coming out from the powder and falls into the water solvent. Every hour, the quercetin concentration was checked and at 9 th $\mathrm{hr}$ it showed maximum of $8.8 \mu \mathrm{g} / \mathrm{ml}$. But the concentration decreases from 10th hr and 11th hr because the flavor colour is partially decreased. In the fermentation process, the quercetin concentration was enhanced and it is found to be $9.6 \mu \mathrm{g} / \mathrm{ml}$. It is more concentration compare with the non fermented extracts, because the quercetin concentration is increased from fermentation extract due the secretion of $\beta$-glucosidase enzyme [6, 11] which may converts rutin to quercetin. This enzyme was produced by Bacillus cereus which converts rutin to form quercetin. So this process of biotransformation of rutin to quercetin carried out by Bacillus cereus.

Table 2. Average absolute relative deviation values

\begin{tabular}{|c|c|c|c|c|}
\hline Time (hr) & $\begin{array}{c}\text { Experimental } \\
\text { values }\end{array}$ & Theoretical values & $\left|\mathbf{E s}^{\text {Exp }}-\mathbf{E s}^{\text {Th }}\right|$ & $\mid$ Es $^{\text {Exp }}-$ Es $^{\text {Th }} \mid$ \\
\hline 1 & 0.0299 & 0.0177 & Es $^{\text {Th }}$ \\
\hline 2 & 0.0358 & 0.0311 & 0.0122 & 0.408027 \\
\hline 3 & 0.0416 & 0.0413 & 0.0047 & 0.131285 \\
\hline 4 & 0.0466 & 0.0490 & 0.0003 & 0.007212 \\
\hline 5 & 0.0524 & 0.0549 & 0.0024 & 0.051502 \\
\hline 6 & 0.0591 & 0.0593 & 0.0025 & 0.04771 \\
\hline 7 & 0.0649 & 0.0627 & 0.0002 & 0.003384 \\
\hline 8 & 0.0708 & 0.0652 & 0.0022 & 0.033898 \\
\hline
\end{tabular}


Table 3. Rate of Substrate consumption (S), Biomass (X), Product formation (P), Enzyme, Product consumption

\begin{tabular}{|c|c|c|c|c|c|c|}
\hline S.No & $\begin{array}{c}\text { Time } \\
\text { (hr) }\end{array}$ & $\begin{array}{c}\text { Product formation } \\
\text { (Quercetin in } \\
\mu \mathrm{g} / \mathrm{ml} \text { ) }\end{array}$ & $\begin{array}{c}\text { Product } \\
\text { Consumption } \\
\text { (Rutin in } \mu \mathrm{g} / \mathrm{ml}) \\
\end{array}$ & $\begin{array}{c}\text { Substrate } \\
(\mathrm{S}) \\
(\mu \mathrm{g} / \mathrm{ml}) \\
\end{array}$ & $\begin{array}{c}\text { Biomass } \\
(\mathrm{X}) \\
(\mu \mathrm{g} / \mathrm{ml})\end{array}$ & $\begin{array}{c}\begin{array}{c}\beta-G l u c o s i d a s e \\
\text { enzyme }\end{array} \\
\text { concentration }(\mathrm{U} / \mathrm{ml}) \\
\end{array}$ \\
\hline 1 & 0 & 8.8 & 6.2 & 20 & 0.80 & 0 \\
\hline 2 & 2 & 8.8 & 6.2 & 19.02 & 0.82 & 0 \\
\hline 3 & 4 & 8.8 & 6.2 & 18.1 & 0.84 & 0 \\
\hline 4 & 6 & 9.0 & 5.8 & 17.7 & 0.86 & 0.02 \\
\hline 5 & 8 & 9.0 & 5.8 & 15.6 & 0.92 & 0.02 \\
\hline 6 & 10 & 9.1 & 5.4 & 14.4 & 0.98 & 0.08 \\
\hline 7 & 12 & 9.2 & 5.2 & 12.3 & 1.02 & 0.11 \\
\hline 8 & 14 & 9.2 & 5.2 & 11.2 & 1.26 & 0.11 \\
\hline 9 & 16 & 9.3 & 4.9 & 10.0 & 1.34 & 0.18 \\
\hline 10 & 18 & 9.3 & 4.9 & 8.7 & 1.56 & 0.18 \\
\hline 11 & 20 & 9.5 & 4.5 & 6.8 & 1.78 & 0.23 \\
\hline 12 & 22 & 9.6 & 4.3 & 5.2 & 2.08 & 0.28 \\
\hline 13 & 24 & 9.6 & 4.3 & 4.7 & 2.32 & 0.28 \\
\hline 14 & 26 & 9.6 & 4.3 & 4.7 & 2.32 & 0.28 \\
\hline
\end{tabular}

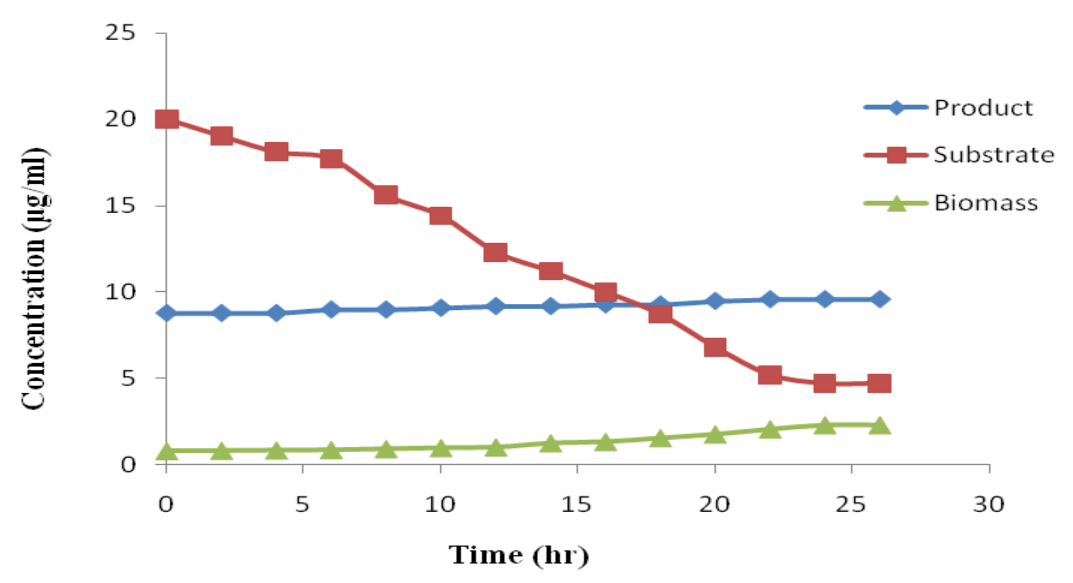

Fig. 1. Rate of Substrate consumption (S), Biomass (X), Product formation (P)

Table 4. Effect of Specific growth rate $\left(\mu_{\max }\right)$

\begin{tabular}{|c|c|c|c|c|c|c|c|}
\hline S.No & Time $(\mathbf{h r})$ & $\mathbf{S}(\boldsymbol{\mu g} / \mathbf{m l})$ & $\mathbf{X}(\boldsymbol{\mu g} / \mathbf{m l})$ & $\mathbf{r}_{\mathbf{x}}$ & $\boldsymbol{\mu}=\mathbf{r}_{\mathbf{x}} / \mathbf{x}$ & $\mathbf{1} / \boldsymbol{\mu}$ & $\mathbf{1 / S}$ \\
\hline 1 & 0 & 20 & 0.80 & 0 & 0 & 0 & 0.05 \\
\hline 2 & 2 & 19.02 & 0.82 & 0.01 & 0.012 & 83.29 & 0.051 \\
\hline 3 & 4 & 18.1 & 0.84 & 0.005 & 0.006 & 165.66 & 0.054 \\
\hline 4 & 6 & 17.7 & 0.86 & 0.010 & 0.011 & 90.89 & 0.055 \\
\hline 5 & 8 & 15.6 & 0.92 & 0.030 & 0.032 & 30.31 & 0.065 \\
\hline 6 & 10 & 14.4 & 0.98 & 0.030 & 0.032 & 32.26 & 0.069 \\
\hline 7 & 12 & 12.3 & 1.02 & 0.020 & 0.020 & 50.01 & 0.081 \\
\hline 8 & 14 & 11.2 & 1.26 & 0.100 & 0.080 & 12.40 & 0.090 \\
\hline 9 & 16 & 10.0 & 1.34 & 0.070 & 0.053 & 18.87 & 0.095 \\
\hline 10 & 18 & 8.7 & 1.56 & 0.100 & 0.070 & 14.00 & 0.112 \\
\hline 11 & 20 & 6.8 & 1.78 & 0.095 & 0.054 & 18.53 & 0.148 \\
\hline 12 & 22 & 5.2 & 2.08 & 0.095 & 0.045 & 21.73 & 0.200 \\
\hline 13 & 24 & 4.7 & 2.32 & 0.090 & 0.0404 & 25.59 & 0.204 \\
\hline
\end{tabular}




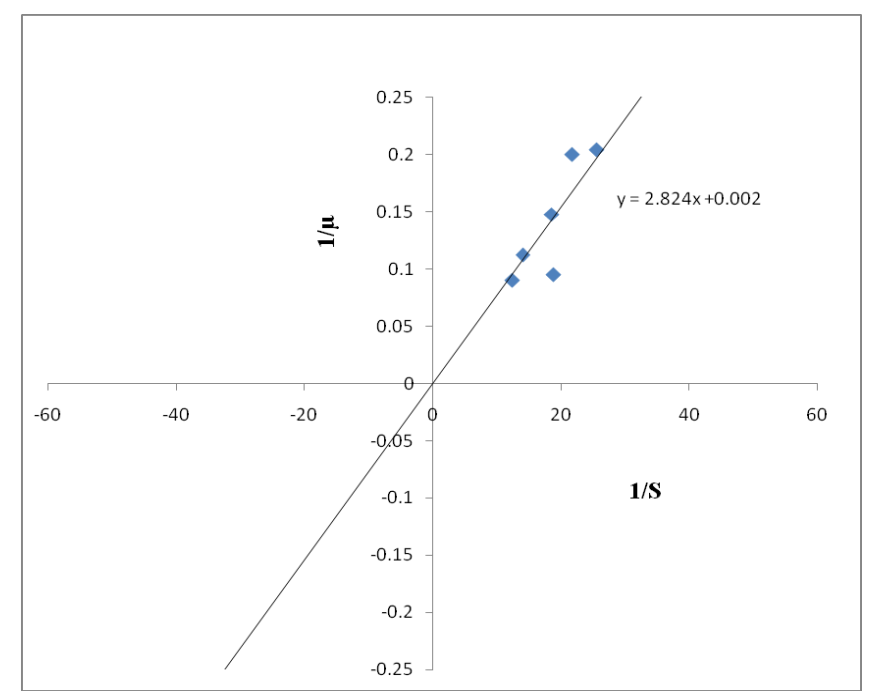

Fig. 2. Effect of Specific growth rate $\left(\mu_{\max }\right)$

Table 5. Effect of Yield factor

\begin{tabular}{|c|c|c|c|c|c|c|c|}
\hline S.No & Time (hr) & $S(\mu \mathrm{g} / \mathrm{ml})$ & $X(\mu \mathrm{g} / \mathrm{ml})$ & $\mathbf{r}_{\mathbf{x}}$ & $\mathbf{r}_{\mathrm{s}}$ & $\mathbf{r}_{\mathbf{x}} / \mathbf{x}$ & $\mathbf{r}_{\mathrm{s}} / \mathbf{x}$ \\
\hline 1 & 0 & 20 & 0.80 & 0 & 0 & 0 & 0 \\
\hline 2 & 2 & 19.02 & 0.82 & 0.01 & 0.500 & 0.013 & 0.602 \\
\hline 3 & 4 & 18.1 & 0.84 & 0.005 & 0.436 & 0.006 & 0.008 \\
\hline 4 & 6 & 17.7 & 0.86 & 0.010 & 0.150 & 0.012 & 0.013 \\
\hline 5 & 8 & 15.6 & 0.92 & 0.030 & 1.170 & 0.032 & 0.037 \\
\hline 6 & 10 & 14.4 & 0.98 & 0.030 & 0.600 & 0.030 & 0.032 \\
\hline 7 & 12 & 12.3 & 1.02 & 0.020 & 0.970 & 0.020 & 0.020 \\
\hline 8 & 14 & 11.2 & 1.26 & 0.100 & 0.680 & 0.079 & 0.549 \\
\hline 9 & 16 & 10.0 & 1.34 & 0.070 & 0.310 & 0.053 & 0.231 \\
\hline 10 & 18 & 8.7 & 1.56 & 0.100 & 0.800 & 0.066 & 0.528 \\
\hline 11 & 20 & 6.8 & 1.78 & 0.095 & 1.020 & 0.054 & 0.597 \\
\hline 12 & 22 & 5.2 & 2.08 & 0.095 & 0.885 & 0.046 & 0.439 \\
\hline 13 & 24 & 4.7 & 2.32 & 0.090 & 0.070 & 0.040 & 0.031 \\
\hline
\end{tabular}

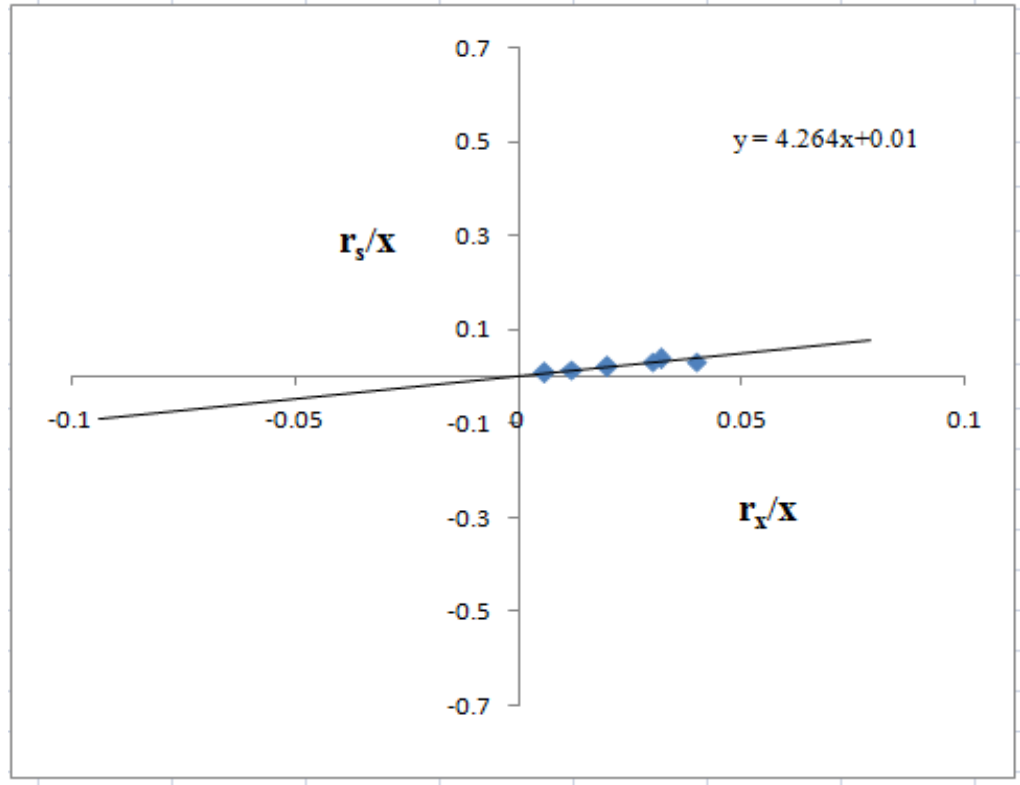

Fig. 3. Effect of Yield factor

\section{DISCUSSION}

In the present work, the leaves of Indian Gooseberry were used to enhance the quercetin concentration by using soxhlet extraction process and its concentration was found to be 8.8 $\mu \mathrm{g} / \mathrm{ml}$. In the soxhlet extraction process, $24 \mathrm{~g}$ of powder is placed in a thimble and $200 \mathrm{ml}$ of water solvent is placed in the conical flask. The water droplets are coming out from the condenser and fall on the powder. In every cycle, only flavor color is coming out from the powder and falls into the water solvent. Every hour, the quercetin concentration was checked and at 9 th $\mathrm{hr}$ it showed maximum of $8.8 \mu \mathrm{g} / \mathrm{ml}$. But the concentration decreases from 10th hr and 11th hr because the flavor colour is partially decreased.

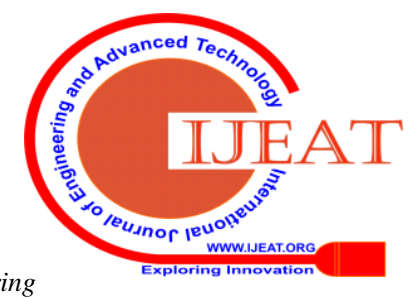


In the fermentation process, the quercetin concentration was enhanced and it is found to be $9.6 \mu \mathrm{g} / \mathrm{ml}$. It is more concentration compare with the non fermented extracts, because the quercetin concentration is increased from fermentation extract due the secretion of $\beta$-glucosidase enzyme $[6,11]$ which may converts rutin to quercetin. This enzyme was produced by Bacillus cereus which converts rutin to form quercetin. So this process of biotransformation of rutin to quercetin carried out by Bacillus cereus.

\section{CONCLUSION}

In the present study, quercetin had shown best results in fermentation process than soxhlet extraction process. The quercetin concentration was enhanced in the fermented extracts is due the secretion of $\beta$-glucosidase enzyme which converts rutin to quercetin. This enzyme was produced by Bacillus cereus. From the non fermented extracts, the highest quercetin concentration was found to be $8.8 \mu \mathrm{g} / \mathrm{ml}$ and the concentration was found to be $9.6 \mu \mathrm{g} / \mathrm{ml}$ from the fermented extracts. Here, it was determined modelling equation of quercetin, maximum specific growth rate ( $\mu$ max) and Yield factor (Yx/s) for Bacillus cereus.

\section{ACKNOWLEDGEMENT}

The authors are grateful to the Meerut Institute of Engineering and Technology, Meerut, Uttar Pradesh, India, and Andhra University, Visakhapatnam, Andhra Pradesh, India, for providing facilities for carry out the research.

\section{CONFLICT OF INTEREST}

The authors declare that they do not have any conflict of interest.

\section{REFERENCES}

1. G. Bhakta Prasad, S. Lalita, Phytochemistry, Pharmacology and Medicinal Properties of Phyllanthus emblica Linn. Chin, J. Integr. Med. 2 (2014) 1-8.

2. K. Avneesh, S. Amanpreet, S. Baljinder. Assessment of therapeutic potential of Phyllanthus emblica (Amla): A natural Godsend, Int. J. Cell Sci. Bio. 3 (2014) 4-14.

3. S. Balasubramanian, D. Ganesh, P. Poonam, T. Mohammad, V.V.S. Surya Narayana, GC-MS analysis of phytocomponents in the ethanolic extract of Emblica officinalis (Indian Gooseberry), J. Chem. Pharm. Res. 6(6) (2014) 843-845.

4. M. Kanthimathi, R. Soranam, Antibacterial effects of Emblica officinalis and Phyllanthus niruri crude extracts against bacterial pathogens, Int. J. Pharm. Cli. Sci. 3(3) (2013) 20-23.

5. P. Avani, P. Amit, Estimation of Flavonoid, Polyphenolic Content and In-vitro Antioxidant Capacity of Phyllanthus embilica, Int. J. Pharm. Sci. Res. 3(2) (2011) 68-73.

6. V. Koppaka Rao, T.W. Nghe, Microbial Transformation of Quercetin by Bacillus cereus, Appl. Environ. Microbiol. 42(3) (1981) 450-452.

7. M. K. F. Nadheesha, A. Bamunuarachchi, E. M. R. K. B. M. Edirisinghe, W. M. S. K. Weerasingh. Studies on antioxidant activity of Indian Gooseberry fruit and seed, J. Sci. Uni. Kelaniya, 3 (2007) 83-92.

8. G. Ankita, S. Sangeeta, Emblica officinalis (Amla) leaf extract potentiates antibacterial activity of some antibiotics, J. Pharm. Phytochem. 6(2) (2017) 233-236.

9. D. A.Vaibhav, K. Arun, Wahi. Immunomodulatory effect of alcoholic extract of Terminalia chebula ripe fruits, J. Pharm. Sci. Res. 2(9) (2012) 539-544.

10. R. Saratha, V. G. Vasudha. Emblica Officinalis (Indian Gooseberry) Leaves Extract as Corrosion Inhibitor for Mild Steel in $1 \mathrm{~N} \mathrm{HCl} \mathrm{Medium,}$ E-J. Chemistry. 7(3) (2010) 677-684.

11. M. Parvathi Nandan, V. Meena, Biotransformation of Flavonol Rutin to Quercetin from Citrus Medica Peel by Using Bacillus Cereus, Int. J. Res. 2(11) (2015) 375-379.

12. C. A. Barber, Enzymic glycosidation of quercetin to rutin, J. Biochemistry. 1 (1962) 463-468.
13. S. Nidhi,M. Chetna, S. Nikhil Anil, R. Saumya, A. Jayanthi, Pharmaceutical Properties of Emblica officinalis and Phyllanthus emblica Extracts, Res. J. Pharm. Bio. Che. Sci. 6(1) (2015) 1007-1016.

14. S. Nyi Mekar, H. Irma Erika, P. Uli Yana, Total flavonoids content in acidified extract of flowers and leaves of gardenia (Gardenia Jasminoides Ellis). A. J. Pharm. Clin. Res. 9(1) (2016) 213-215.

15. H. Arima, H. Ashida H, G. Danno, Rutin-enhanced antibacterial activities of flavonoids against Bacillus cereus and Salmonella enteritidis, Biosci. Biotechnol. Biochem. 66 (5) (2002)1009-14.

16. A.I. Bagudo, A. U. Argungu, A. A. S. Aliero, N. Suleiman, S. Kalpana, Bacillus subtilis as an Alternative Source of Beta-glucosidase, Int. J. Mod. Mol. Bio. 3 (1) (2014) 1-9.

17. R. Phattarakorn, R. Nuchanart, S. Jutamaad, G. Motonobu, S. Artiwan. Subcritical water extraction of polyphenolic compounds from Terminalia chebula fruits, J. Sep. Purification Technol. 66 (2009) 51-56.

18. A.C. Kumoro, M. Hasan, Modelling of andrographolide extraction from andrographis paniculata leaves in a soxhlet extractor, Internationa Conference on Natural Resources Engineering and Technology 2006.

19. N. Sree Satya, V. Meena, Monod Kinetics of Cinnamaldehyde from Methanolic extract of Cinnamon species, Asian J. Biochem. Pharm. Res. 2(4) (2012) 93-98.

20. J.P. Haluk, M. Metche, Microbiological transformation of quercetin by Aspergillus niger, Bull.Soc. Chim. Biol. 52 (1970) 667- 677.

21. D. Usha Priyanka, C.H. Kanakaraju, A. Sumanjali, K. Dwaraka, V. Meena, Critical studies on kinetic parameters for the production of protease from SSF by Bacillus subtilis NCIM 2724, Int. J. Che. Sci. 8 (2) (2010) 935-942.

22. H.C. Krishnamurty, F. J. Simpson, Degradation of rutin by Aspergillus flavus, J. Biol. Chem. 245 (1970) 1467-1471.

\section{AUTHORS PROFILE}

Dr. Surya Prakash is the Assistant Professor in the Department of Biotechnology, Department of Biotechnology, Meerut Institute of Engineering and Technology, Meerut, Uttar Pradesh. His area of research is Bioprocess Engineering, Medicinal plants, Industrial Biotechnology and Fermentation Technology. He published 20 research papers in reputed journals like UGC, Scopus Indexed and SCI. Also nearly 15 papers contribution in national and international conferences.

He invited as a guest lecturer in government and reputed Engineering colleges. He is an Member of the ISCA, a Member of Society for Applied Biotechnology and BRSI, India.

Anand Kumar Nelapati is a Ph.d scholar and project assistant at Department of Chemical Engineering, NITK, Surathkal, Mangalore, India. His area of research is Chemical Engineering, Chemical process plant design and Chemical reaction Engineering and Fermentation Technology. He published 10 research papers in reputed journals like UGC, Scopus Indexed and SCI. Also nearly 12 papers contribution in national and international conferences.

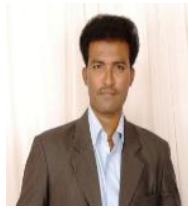

Dr.T.Mohammad Munawar $\mathrm{He}$ is the Assistant Professor in the Department of BCEN at Mekelle Institute of Technology (MIT), Mekelle University, Mekelle, Ethiopia. His area of research is Biochemical Engineering, Fermentation technology, Bionanotechnology and Biofuels. He published 28 research papers in reputed journals like UGC, Scopus Indexed and SCI. Also nearly 14 papers contribution in national and international conferences. He invited as a guest lecturer in government and reputed Engineering colleges across india and Ethiopia. He is an Member of The Institution of Engineers, a life member of ISTE, Member of Indian science congress of Association and member of All Indian Biotechnologist Association. 